\title{
Genetic Diversity of Tomato (Solanum lycopersicum L.) Begomovirus in Togo
}

\author{
Assion Sétu Mivedor ${ }^{1,2}$, Justin Simon Pita ${ }^{3}$, Kossikouma Djodji Adjata1 ${ }^{*}$, \\ Jérôme Duclercq², Yawovi Mawuena Dieudonné Gumedzoe ${ }^{1}$
}

${ }^{1}$ Laboratory of Plant Virology and Biotechnology (LVBV): Ecole Supérieure d'Agronomie (ESA)/University of Lome, Lomé, Togo ${ }^{2}$ Laboratory of Agroecology, Ecophysiology and Integrative Biology (AEB), Unit EDYSAN FRE 3498 CNRS/University of Picardie Jules Verne, Amiens, France

${ }^{3}$ Université Félix Houphouët-Boigny, Laboratory of Plant Virology, Pôle Scientifique et d'Innovation, Bingerville, Côte d'Ivoire

Email: *dadjata@yahoo.fr

How to cite this paper: Mivedor, A.S., Pita, J.S., Adjata, K.D., Duclercq, J. and Gumedzoe, Y.M.D. (2017) Genetic Diversity of Tomato (Solanum lycopersicum L.) Begomovirus in Togo. Agricultural Sciences, 8, 1402-1414.

https://doi.org/10.4236/as.2017.812100

Received: October 5, 2017

Accepted: December 26, 2017

Published: December 29, 2017

Copyright (C) 2017 by authors and Scientific Research Publishing Inc. This work is licensed under the Creative Commons Attribution International License (CC BY 4.0).

http://creativecommons.org/licenses/by/4.0/

\begin{abstract}
Geminiviruses, in particular the members of the genus Begomovirus, are considered to be a major phytosanitary problem for tomato crops production in the world. They are responsible for yield losses of up to $20 \%$ to $100 \%$. Regrettably, Togo is not spared from this situation. This work aims to show the genetic diversity of the begomoviruses affecting tomato crops production in Togo and their relationship with other begomoviruses. To achieve these objectives, 307 samples of tomato leaves and wild plant species with typical virus symptoms were collected in the Maritime, Plateaus, Central, Kara and Savannah regions and submitted to PCR analysis. The results revealed the presence of begomovirus in $25.40 \%$ of the analyzed samples. The PCR products obtained were submitted to direct sequencing. Phylogenetic analysis of sequences of DNA-A different regions of begomovirus identified in this work with that of other begomoviruses showed a nucleotide identity of $96 \%$ respectively for Tomato leaf curl Togo virus-Fontem, Tomato Leaf Curl Togo Virus, Ageratum leaf curl Cameroon Alphasatellite, 98\% respectively to Tomato leat curl Nigeria virus, Ageratum leaf curl Cameroon virus, Tomato leaf curl Cameroon virus-Fontem, Ageratum leaf curl Cameroon virus and 99\% respectively to Tomato leaf curl Kumasi virus, Pepper yellow vein Mali virus Bazegahot and Pepper yellow vein Mali virus-Ouaga. These results suggest a high degree of genetic diversity of tomato begomoviruses identified in Togo.
\end{abstract}

\section{Keywords}

Begomoviruses, Direct Sequencing, Phylogenetic Relationships, Tomato, Wild Plants 


\section{Introduction}

Begomoviruses, transmitted in persistent, circulative manner by Bemisia tabaci Gennadius (Homoptera: Aleyrodidae), are a major limiting factor for the production of many agricultural species in tropical and subtropical regions of the world [1]. In particular, approximately 70 species of the genus Begomovirus (family Geminiviridae) have been identified as naturally infecting tomato (Solanum lycopersicum L.) in different parts of the world [2] [3] and even in some places, these diseases have eliminated the tomato as an economically viable crop [4] [5].

The diversity of geminiviruses is reflected in seven genera (Becurtovirus, Begomovirus, Curtovirus, Eragrovirus, Mastrevirus, Topocuvirus and Turncurtovirus), which are defined on the basis of genome structure, host range and insect vector [6] [7]. With 288 species currently recognized by the International Committee of Taxonomy of Viruses (ICTV), the genus Begomovirus is the largest genus of plant viruses in relation to the number of members it includes (http://www.ictvonline.org/virusTaxonomy.asp). Their genome is a singlestranded circular DNA that can be monopartite (containing DNA-A) or bipartite (containing both genomic DNA-A and B) [8] .

Based on genome organization, phylogenetic relationship and geographic distribution, begomoviruses have generally been divided into two groups: the begomoviruses of the Old World (Europe, Africa, Asia and Australia) and the begomoviruses of the New World (Americas) [9]. Most bipartite begomoviruses are found in the New World, while most monopartite species are found in the Old World. However, there are exceptions. Bipartite begomoviruses such as Tomato leaf curl New Delhi virus (ToLCNDV) [10] and Tomato yellow leaf curl Thailand virus (TYLCTHV) [11] are distributed in the Old World, while the monopartite Tomato yellow leaf curl virus (TYLCV) was introduced in the New World in the early 1990s and it is now widespread in the Caribbean basin and in the South America (Hawaii, Mexico and Guatemala) [12].

Contrary to the considerable genetic diversity that exists among begomoviruses infecting tomato crops, the symptoms induced by these viruses are relatively similar and include varying degrees of stunting, leaf curling, mottling and yellowing. In addition, symptoms vary depending on the cultivar, host plant species, age of the plant at the infection time, environmental factors and mixed infections with other viruses or pathogens. Thus it is difficult, if not impossible, to identify the species involved in an outbreak based solely on symptoms, hence the importance of a molecular analysis for the identification of these viruses.

In Western Africa begomoviruses have emerged recently and are caused by genetically distinct species that have evolved locally, hence these regions could be an important area for new evolutionary linkages of the species within the genus [4] [13] [14] [15].

The work aimed at studying the genetic diversity of begomoviruses infecting tomato and associated wild plants in tomato fields in Togo. 


\section{Material and Methods}

\subsection{Sample Collection}

A total of 307 samples of tomato leaves and wild plants showing typical symptoms of begomoviruses; leaf curling, yellowing, stunting and leaf thickening (Figure 1) were collected in 2013, 2014 and 2015 from Maritime, Plateaus, Central, Kara and Savannah regions in Togo (Table 1). Samples were also collected on wild plants in tomato fields for the search of inoculum sources of begomoviruses. For molecular analyses, samples were dried in an oven at $40^{\circ} \mathrm{C}$. It is important to notice that the variability in the number of collected samples is due to the fact that the sampling protocol used, required that tomato fields should be separated from each other of $10 \mathrm{~km}$ in order to take geo-referenced positions.

\subsection{DNA Extraction and PCR Running}

Total nucleic acids were extracted from symptomatic tomato plants and wild plants through the methods adapted by [16]; $150 \mathrm{mg}$ of desiccated tissue was ground in $500 \mu \mathrm{L}$ of extraction buffer ( $2 \%$ de CTAB, $1,4 \mathrm{M} \mathrm{NaCl}, 20 \mathrm{mM}$ EDTA, $100 \mathrm{mM}$ Tris- $\mathrm{HCl}, 1 \% \mathrm{PVP}, \mathrm{pH} 8,0$ and $0,2 \% \beta$-mercaptoéthanol) and incubated at $60^{\circ} \mathrm{C}$ for $30 \mathrm{~min}$. The mixture was kept on ice for $10 \mathrm{~min}$ followed by centrifugation at $13,000 \mathrm{rpm}$ for 15 minutes at $4^{\circ} \mathrm{C}$. The supernatant was transferred to a new vial and diluted with distilled water before using in Polymerase Chain Reaction (PCR) reaction.

Begomoviruses identification was performed by PCR using six pairs of universal primers able to amplify the different regions of the component DNA-A
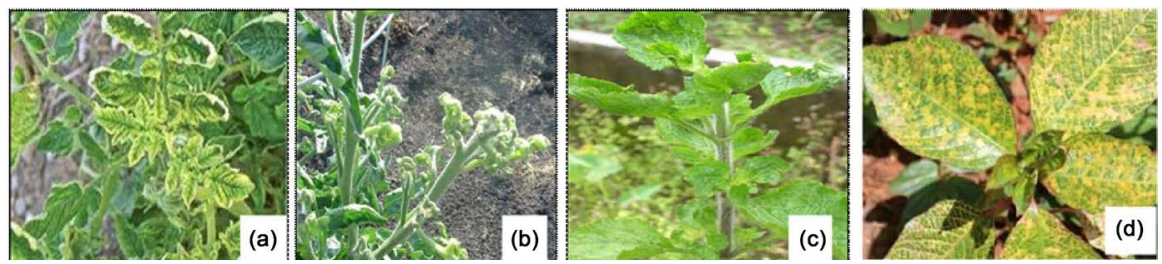

Figure 1. Solanum lycopersicum plants from Togo with leaf curl and yellowing symptoms (a), stunting symptoms (b), Ageratum conyzoides with leaf curl symptoms (c) and Euphorbia heterophylla with mosaic symptoms.

Table 1. Number of tomato and wild plants infected leaf samples in tomato production regions in Togo.

\begin{tabular}{ccc}
\hline Regions & Samples from Tomato & Samples from wild plants \\
\hline Maritime & 41 & 54 \\
Plateaus & 8 & 5 \\
Central & 11 & 5 \\
Kara & 74 & 32 \\
Savannah & 46 & 31 \\
Total & 180 & 127 \\
\hline
\end{tabular}


Table 2. Primers used in this study.

\begin{tabular}{|c|c|c|c|c|c|}
\hline Primers & 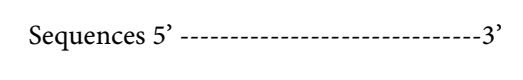 & $\begin{array}{l}\text { Length } \\
\text { (bp) }\end{array}$ & $\begin{array}{l}\text { Amplified region } \\
\text { (DNA-A) }\end{array}$ & PCR Conditions & References \\
\hline $\begin{array}{l}\text { AVcore } \\
\text { ACcore }\end{array}$ & $\begin{array}{l}\text { GCCHATRTAYAGRAAGCCNAGRAT } \\
\text { GGRTTDGARGCATGHGTACANGCC }\end{array}$ & 575 & $\mathrm{CP}$ & $\begin{array}{l}94^{\circ} \mathrm{C} / 2 \mathrm{~min}, 35 \times\left(94^{\circ} \mathrm{C} 1 \mathrm{mn} / 60^{\circ} \mathrm{C} 2\right. \\
\left.\mathrm{mn} / 72^{\circ} \mathrm{C} 2 \mathrm{mn}\right) 72^{\circ} \mathrm{C} / 10 \mathrm{~min}\end{array}$ & [17] \\
\hline $\begin{array}{l}\text { Av494 } \\
\text { Ac1048 }\end{array}$ & $\begin{array}{l}\text { GCCYATRTAYAGRAAGCCMAG } \\
\text { GGRTTDGARGCATGHGTACATG }\end{array}$ & 550 & $\mathrm{CP}$ & $\begin{array}{l}94^{\circ} \mathrm{C} / 2 \mathrm{~min}, 35 \times\left(94^{\circ} \mathrm{C} 1 \mathrm{mn} / 55^{\circ} \mathrm{C} 2\right. \\
\left.\mathrm{mn} / 72^{\circ} \mathrm{C} 1 \mathrm{mn}\right) 72^{\circ} \mathrm{C} / 10 \mathrm{~min}\end{array}$ & [18] \\
\hline $\begin{array}{l}\text { Deng A } \\
\text { Deng B }\end{array}$ & $\begin{array}{l}\text { TAATATTACCKGWKGVCCSC } \\
\text { TGGACYTTRCAWGGBCCTTCACA }\end{array}$ & 520 & $\mathrm{CP}$ & $\begin{array}{l}94^{\circ} \mathrm{C} / 2 \mathrm{~min}, 30 \times\left(94^{\circ} \mathrm{C} 1 \mathrm{mn} / 61^{\circ} \mathrm{C} 1\right. \\
\left.\mathrm{mn} / 72^{\circ} \mathrm{C} 2 \mathrm{mn}\right) 72^{\circ} \mathrm{C} / 10 \mathrm{~min}\end{array}$ & [19] \\
\hline $\begin{array}{l}\text { PALIc } 1960 \\
\text { PARIv } 722 \\
\text { PAR1c } 496 \\
\text { PCRv } 181\end{array}$ & $\begin{array}{l}\text { ACNGGNAARACNATGTGGGC } \\
\text { GGNAARATHTGGATGGA } \\
\text { AATACTGCAGGGCTTYCTRTACATRGG } \\
\text { TAATATTACCGGWTGGCC }\end{array}$ & 1200 & $\begin{array}{l}\mathrm{AC} 1, \mathrm{AC} 2, \mathrm{AC} 3 \\
\mathrm{CP}\end{array}$ & $\begin{array}{l}94^{\circ} \mathrm{C} / 2 \mathrm{~min}, 30 \times\left(94^{\circ} \mathrm{C} 1 \mathrm{mn} / 55^{\circ} \mathrm{C} 2\right. \\
\left.\mathrm{mn} / 72^{\circ} \mathrm{C} 2 \mathrm{mn}\right) 72^{\circ} \mathrm{C} / 10 \mathrm{~min}\end{array}$ & [20] \\
\hline $\begin{array}{l}\text { TYv } 2664 \\
\text { TYc138 }\end{array}$ & $\begin{array}{l}\text { ATTGACCAAGATTTTTACACTTATCCC } \\
\text { AAGTGGGTCCCACATATTGCAAGAC }\end{array}$ & 316 & IR & $\begin{array}{l}94^{\circ} \mathrm{C} / 5 \mathrm{~min}, 30 \times\left(94^{\circ} \mathrm{C} / 1 \mathrm{~min}, 62^{\circ} \mathrm{C} / 45 \mathrm{sec},\right. \\
\left.72^{\circ} \mathrm{C} / 1 \mathrm{~min} .\right), 1 \times\left(94^{\circ} \mathrm{C} / 1 \mathrm{~min}, 56^{\circ} \mathrm{C} / 1 \mathrm{~min} \text {, }\right. \\
\left.72^{\circ} \mathrm{C} / 10 \mathrm{~min}\right)\end{array}$ & [21] \\
\hline
\end{tabular}

$\mathrm{D}=\mathrm{A}, \mathrm{G}, \mathrm{T} ; \mathrm{H}=\mathrm{A}, \mathrm{C}, \mathrm{T} ; \mathrm{K}=\mathrm{G}, \mathrm{T} ; \mathrm{M}=\mathrm{A}, \mathrm{C} ; \mathrm{N}=\mathrm{A}, \mathrm{C}, \mathrm{G}, \mathrm{T} ; \mathrm{R}=\mathrm{A}, \mathrm{G} ; \mathrm{W}=\mathrm{A}, \mathrm{T} ; \mathrm{Y}=\mathrm{C}, \mathrm{T}$

according to protocols of [17] [18] [19] [20] and [21] (Table 2). The universal primer pair Avcore/ACcore [17] which amplify a 575 nucleotide fragment corresponding to the core region of coat protein $(\mathrm{CP})$ gene of almost all begomoviruses. Two sets of Begomovirus group specific universal primers Deng A/Deng B primers [19] and Av494/Ac1048 [18] which are capable to amplify the core CP of many begomoviruses were used for viral detection. The primer pair PALIc1960/PARI722 produces a $1.2 \mathrm{~Kb}$ band upon PCR and had been designed to amplify the bottom half region of the A genome component of most WTGs [20]. Primers PAR1c496/PCRv181 [20] amplify 300 bp of the A component that contains $\sim 172 \mathrm{bp}$ of region between the beginning of the loop and the beginning of the CP and 126 bp of the CP. Primers TYv2664/TYc138 were used to amplify the IR of TYLCV-Mld.

The parameters for the PCR reaction were optimized for $25 \mu$. The final concentrations of reaction components were: $200 \mu \mathrm{M}$ deoxynucleotide triphosphate (dNTPs), 1x Taq DNA polymerase buffer, $2.5 \mathrm{mM} \mathrm{MgCl}_{2}, 0.8$ units Taq DNA polymerase, $1 \mu \mathrm{M}$ of each complementary and virus-sense primers and $2 \mu \mathrm{l}$ of DNA. PCR cycle parameters were as described in Table 2. All PCR reactions were performed in a programmable thermocycler (Mastercycler ep gradient $S$, Eppendorf, Hamburg, Germany).

The amplified products, along with $10 \mathrm{~kb}$ DNA ladder, were resolved in 1\% agarose gel in Tris-borate EDTA (TBE), pH 8.0 buffer with $10 \mu \mathrm{l} / 100 \mathrm{ml}$ GelGreenTM. Gel electrophoresis was carried out at $70 \mathrm{~V}$ until tracking dye has reached the bottom of the gel. The DNA bands were viewed and photographed using a gel documentation system (BioRad, Hercules, CA, USA). 


\subsection{Sequencing and Phylogenetic Analysis}

PCR products from amplifications were purified using the Agentcourt AMPure XP magnetic beads (Beckman Coulter, Inc. 250 S. Kraemer Blvd. Brea, CA 92821 USA) according to the manufacturer's protocol. The Illumina Nextera XT Index kit (Illumina Inc., San Diego, CA, USA) was used according to the manufacturer's instructions to assign a code to each sample prior to sequencing. The purity of the PCR products was verified at the Agilent Bioanalyzer 2100 (Agilent Technologies, Palo Alto, CA, USA) and the sequencing was performed at the UPJV Molecular Biology platform via the high throughput technique using the kit V2 of the Illumina Miseq (Illumina Inc., San Diego, CA, USA).

The partial sequences were assembled using the FROG software (http://bioinfo.genotoul.fr/fileadmin/user_upload/FROGS_poster_Jobim_2015.p df) and aligned with the sequences available in the GenBank database using the BLASTn algorithm (http://www.ncbi.nlm.nih.gov). The multiple alignment of the sequences was obtained with the ClustalX software [22] with default parameters. Phylogenetic analyze was performed by the Neighbor-Joining method using Darwin5. A thousand Bootstrap replicas were used to evaluate the robustness of the topology of the final tree. The nucleotide sequences of isolates Tomato geminiviruses Lebanon (TOGV-LB), Tomato geminiviruses Gezira (TOGV-SD), Tomato yellow leaf curl virus-Puerto Rico (TYLCV-PR), Tomato geminiviruses Kuwait (TYLCV-KU), Tomato yellow leaf curl virus-Reunion (TYLCV-RU), Tomato yellow leaf curl virus-Egypt (TYLCV-EG), Tomato yellow leaf curl virus-Israel (TYLCV-IS), Tomato yellow leaf curl virus-Mild [Spain7297] (TYLCV-SP), Tomato yellow leaf curl virus-Mild [Shizuokua] (TYLCV-JP), Tomato yellow leaf curl virus-Cuba (TYLCV-CU), Tomato yellow leaf curl Mali virus (TYLCV-ML), Tomato leaf curl Nigeria virus (ToLCNGV), Tomato leaf curl Cameroon virus-Fontem (ToLCCMV-Fontem) and Pepper yellow vein Mali virus-Ouagadougou (PepYVMLV-OUAGA) were included in the analysis.

\section{Results}

\subsection{Begomoviruses Identification by PCR}

A total of 307 samples among with, 180 samples from tomatoes and 127 from wild plants were collected and based on PCR analysis, 66 tomatoes and 12 wild plants were revealed to be positive for the presence of begomoviruses. In the Maritime Region, $10.52 \%$ of the samples analyzed were positive, $53.84 \%$ in the Plateaus region, $31.25 \%$ in the Central Region, $44.33 \%$ in the Kara region and $11.68 \%$ in the Savannah region (Table 3). Surprisingly, no infection by begomoviruses was reported in Kpendjal Prefecture. These results could suggest that the insect vector B. tabaci is not present in the environment. The results obtained from PCR showed that the isolate TYLCV-Mild was not detected in all the collected samples. Different fragment sizes were obtained from five geminiviruses 
Table 3. Percentage of samples infected by begomoviruses in the five economic regions of Togo.

\begin{tabular}{|c|c|c|c|c|c|}
\hline Regions of Togo & $\begin{array}{l}\text { Number of collected samples } \\
\text { tomatoes (Solanum lycopersicum) }\end{array}$ & $\begin{array}{l}\text { Number of samples } \\
\text { reacted positively to PCR }\end{array}$ & $\begin{array}{l}\text { Number of collected } \\
\text { samples wild plants }\end{array}$ & $\begin{array}{l}\text { Number of samples } \\
\text { reacted positively to PCR }\end{array}$ & $\begin{array}{c}\text { Percent disease } \\
\text { incidence (\%) }\end{array}$ \\
\hline Maritime & 41 & 8 & 54 & 2 & 10.52 \\
\hline Plateaus & 8 & 5 & 5 & 2 & 53.84 \\
\hline Central & 11 & 5 & 5 & 0 & 31.25 \\
\hline Kara & 74 & 44 & 32 & 3 & 44.33 \\
\hline Savannah & 46 & 4 & 31 & 5 & 11.68 \\
\hline Total of Togo & 180 & 66 & 127 & 12 & 25.40 \\
\hline
\end{tabular}

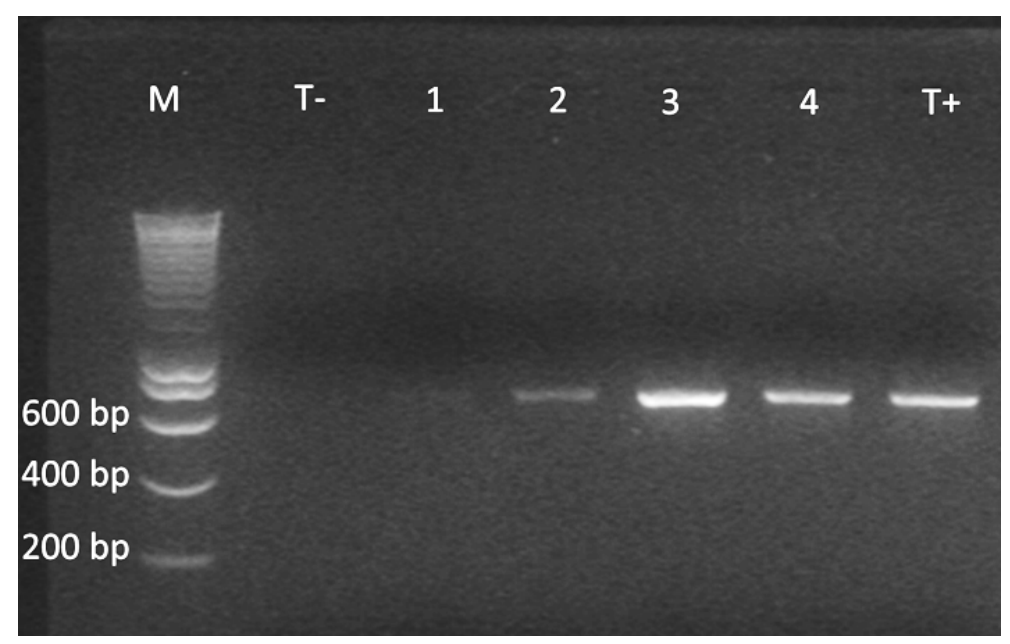

Figure 2. Electrophoretogram with the pair of primers AVcore/ACcore giving fragments of approximately 700 base pairs. $\mathrm{M}=$ marker, $1,2,3$ and $4=$ tomato samples, $\mathrm{T}+=$ positive control, $\mathrm{T}-=$ negative control.

primer pairs (Figure 2).

\subsection{Sequence Analysis and Identification of New Viruses}

A total of 123 PCR products including 111 from tomato and 12 from wild plants were fully sequenced to identify the different species of the genus Begomovirus. Partial sequences up to 500 nucleotides were obtained from each reaction and processed with the FROG software

(http://bioinfo.genotoul.fr/fileadmin/user_upload/FROGS_poster_Jobim_2015.p df). These partial sequences were compared to sequences published in GenBank using the BLASTn algorithm (http://www.ncbi.nlm.nih.gov). This comparison showed that the degree of similarity was between $95 \%$ and $100 \%$. Moreover, the alignment enabled to observe that 11 sequences were close to Tomato leaf curl $\mathrm{Ni}$ geria virus (FJ685621.1), 15 to Ageratum leaf curl Cameroon virus (FR873228.1; FR873230; FN675292.1), 7 to Tomato leaf curl Kumasi virus (EU847739.1; FM210063.1; FM210062.1), 2 to Tomato leaf curl Togo virus (FJ685620.1; HE659517.1), 1 from Tomato leaf curl Cameroon virus-Fontem (HE659516.1), 1 to Pepper yellow vein Mali virus-Bazegahot (FM876848.1) and 1 to Pepper 
yellow vein Mali virus-Ouaga (FM876851.1). 123 PCR products were fully sequenced but only 49 sequences available were obtained among which 10 did not show any similarity with Genbank sequences (Table 4).

\subsection{Phylogenetic Analysis}

Phylogenetic analysis was performed with the partial sequences of Togo isolates and control sequences available in GenBank using ClustalX multiple alignment software. The phylogenetic tree was designed using the DARWin5 program and the Neighbor-Joining method. Of the positive PCR samples, 44 sequences from tomato and 4 from wild plants were selected for phylogenetic analysis. This analysis indicated that the Begomoviruses isolated in Togo form seven groups (Figure 3). Groups 1 and 2 contain begomovirus isolates from tomato and two from wild plants Solanum macrocarpon (L.) and Euphorbia heterophylla (L.). Groups 3, 4 and 5 contain only Begomovirus isolates from tomato. Most of GenBank isolates and Group 7 contain both GenBank and tomato isolates.

Table 4. Comparison of Begomovirus sequences isolated in Togo with those of Genbank.

\begin{tabular}{|c|c|c|c|c|}
\hline $\mathrm{N}^{\circ}$ & Origin & $\begin{array}{c}\text { Code of samples and } \\
\text { host plants }\end{array}$ & Genbank virus & $\begin{array}{l}\text { Degree of } \\
\text { similarity }\end{array}$ \\
\hline 1 & Maritime Region & 16-83a/2014 (Tomato) & Ageratum leaf curl Cameroon virus [CM:AGFG24:2009] |FR873228.1| & $98 \%$ \\
\hline 2 & Maritime Region & 16-83b/2014 (Tomato) & Tomato leaf curl Togo virus-Fontem |HE659517.1| & $96 \%$ \\
\hline 3 & Maritime Region & 16-83c/2014 (Tomato) & Tomato leaf curl Nigeria virus-[Nigeria:2006] |FJ685621.1 & $98 \%$ \\
\hline 4 & Maritime Region & 16-83f/2014 (Tomato) & No found & NS \\
\hline 5 & Maritime Region & 16-93/2014 (Tomato) & No found & NS \\
\hline 6 & Maritime Region & $35-71 \mathrm{a} / 2013$ (Tomato) & No found & NS \\
\hline 7 & Maritime Region & 35-71b/2013 (Tomato) & No found & NS \\
\hline 8 & Maritime Region & $35-76 / 2013$ (Tomato) & Tomato leaf curl Togo virus-[Togo:2006] |FJ685620.1| & $96 \%$ \\
\hline 9 & Maritime Region & $35-82 / 2013$ (Tomato) & Tomato leaf curl Nigeria virus-[Nigeria:2006] |FJ685621.1| & $99 \%$ \\
\hline 10 & Central Region & 30-233/2014 (Tomato) & Tomato leaf curl Nigeria virus-[Nigeria:2006] |FJ685621.1| & $99 \%$ \\
\hline 11 & Central Region & $27-235 \mathrm{a} / 2014$ (Tomato) & Ageratum leaf curl Cameroon virus [CM:AGFG24:2009] |FR873228.1| & $99 \%$ \\
\hline 12 & Central Region & 27-235b/2014 (Tomato) & Tomato leaf curl Nigeria virus-[Nigeria:2006] |FJ685621.1| & $99 \%$ \\
\hline 13 & Central Region & $27-235 \mathrm{c} / 2014$ (Tomato) & Tomato leaf curl Kumasi virus clone (GOTB2-2)|EU847739.1| & $99 \%$ \\
\hline 14 & Central Region & $27-235 \mathrm{~d} / 2014$ (Tomato) & Ageratum leaf curl Cameroon virus [CM:AGFG23:2009] |FR873230.1| & $98 \%$ \\
\hline 15 & Central Region & $27-235 \mathrm{e} / 2014$ (Tomato) & Ageratum leaf curl Cameroon alphasatellite [CM:ODL1D1:Ok:09] |FN675292.1| & $96 \%$ \\
\hline 16 & Plateaus Region & 25-10a/2015 (Tomato) & No found & NS \\
\hline 17 & Plateaus Region & 25-11a/2015 (Tomato) & Tomato leaf curl Kumasi virus clone (GOTB2-2)|EU847739.1| & $96 \%$ \\
\hline 18 & Kara Region & 5-272a/2014 (Tomato) & Ageratum leaf curl Cameroon virus [CM:AGFG23:2009] |FR873230.1| & $97 \%$ \\
\hline 19 & Kara Region & 5-272b/2014 (Tomato) & Tomato leaf curl Kumasi virus partial V1 AMJ11|FM210063.1| & $98 \%$ \\
\hline
\end{tabular}




\section{Continued}

\begin{tabular}{|c|c|c|c|c|}
\hline 20 & Kara Region & 5-272c/2014 (Tomato) & Ageratum leaf curl Cameroon virus [CM:AGFG24:2009] |FR873228.1| & $97 \%$ \\
\hline 21 & Kara Region & $5-278 / 2014$ (Tomato) & Ageratum leaf curl Cameroon virus [CM:AGFG24:2009] |FR873228.1| & $97 \%$ \\
\hline 22 & Kara Region & 5-279a/2014 (Tomato) & Ageratum leaf curl Cameroon virus [CM:AGFG24:2009] |FR873228.1| & $97 \%$ \\
\hline 23 & Kara Region & 5-279b/2014 (Tomato) & Tomato leaf curl Kumasi virus partial V1 LIONGO1 |FM210062.1 & $99 \%$ \\
\hline 24 & Kara Region & $5-279 \mathrm{c} / 2014$ (Tomato) & Tomato leaf curl Kumasi virus partial V1 AMJ11 |FM210063.1| & $97 \%$ \\
\hline 25 & Kara Region & $5-281 / 2014$ (Tomato) & Ageratum leaf curl Cameroon virus [CM:AGFG24:2009] |FR873228.1| & $98 \%$ \\
\hline 26 & Kara Region & $8-250 / 2014$ (Tomato) & Ageratum leaf curl Cameroon virus [CM:AGFG24:2009] |FR873228.1| & $96 \%$ \\
\hline 27 & Kara Region & $8-252 / 2014$ (Tomato) & Ageratum leaf curl Cameroon virus [CM:AGFG24:2009] |FR873228.1| & $97 \%$ \\
\hline 28 & Kara Region & $\begin{array}{c}\text { 8-260a/2014 (Euphorbia } \\
\text { heterophylla) }\end{array}$ & Tomato leaf curl Nigeria virus-[Nigeria:2006] |FJ685621.1| & $99 \%$ \\
\hline 29 & Kara Region & $\begin{array}{c}\text { 8-260b/2014 (Euphorbia } \\
\text { heterophylla) }\end{array}$ & No found & NS \\
\hline 30 & Kara Region & $\begin{array}{c}\text { 8-260c/2014 (Euphorbia } \\
\text { heterophylla) }\end{array}$ & No found & NS \\
\hline 31 & Kara Region & 14-226a/2014 (Tomato) & Ageratum leaf curl Cameroon virus [CM:AGFG24:2009] |FR873228.1| & $98 \%$ \\
\hline 32 & Kara Region & $14-226 \mathrm{~b} / 2014$ (Tomato) & Tomato leaf curl Cameroon virus - Fontem |HE659516.1| & $98 \%$ \\
\hline 33 & Kara Region & $14-226 \mathrm{c} / 2014$ (Tomato) & Tomato leaf curl Kumasi virus partial V1 LIONGO1 |FM210062.1| & $98 \%$ \\
\hline 34 & Kara Region & $14-226 \mathrm{~d} / 2014$ (Tomato) & Tomato leaf curl Nigeria virus-[Nigeria:2006] |FJ685621.1| & $98 \%$ \\
\hline 35 & Kara Region & 14-227/2014 (Tomato) & Ageratum leaf curl Cameroon virus [CM:AGFG24:2009] |FR873228.1| & $96 \%$ \\
\hline 36 & Kara Region & 20-182a/2014 (Tomato) & Tomato leaf curl Kumasi virus clone (GOTB2-2)|EU847739.1| & $97 \%$ \\
\hline 37 & Kara Region & $20-182 \mathrm{~b} / 2014$ (Tomato) & Ageratum leaf curl Cameroon virus [CM:AGFG24:2009] |FR873228.1| & $98 \%$ \\
\hline 38 & Kara Region & 20-185/2014 (Tomato) & Tomato leaf curl Nigeria virus-[Nigeria:2006] |FJ685621.1| & $98 \%$ \\
\hline 39 & Kara Region & 20-187/2014 (Tomato) & Tomato leaf curl Kumasi virus clone (GOTB2-2)|EU847739.1| & $99 \%$ \\
\hline 40 & Kara Region & 20-194/2014 (Tomato) & Ageratum leaf curl Cameroon virus [CM:AGFG24:2009] |FR873228.1| & $98 \%$ \\
\hline 41 & Kara Region & $20-215 \mathrm{a} / 2014$ (Tomato) & Tomato leaf curl Nigeria virus-[Nigeria:2006] |FJ685621.1| & $98 \%$ \\
\hline 42 & Kara Region & 20-215b/2014 (Tomato) & Tomato leaf curl Nigeria virus-[Nigeria:2006] |FJ685621.1| & $98 \%$ \\
\hline 43 & Kara Region & $\begin{array}{c}\text { 20-216/2014 (Solanum } \\
\text { macrocarpon) }\end{array}$ & No found & NS \\
\hline 44 & Kara Region & 20-248/2014 (Tomato) & Tomato leaf curl Nigeria virus-[Nigeria:2006] |FJ685621.1| & $99 \%$ \\
\hline 45 & Kara Region & 20-266a/2014 (Tomato) & Pepper yellow vein Mali virus-Ouaga |FM876851.1| & $99 \%$ \\
\hline 46 & Kara Region & 20-266b/2014 (Tomato) & Pepper yellow vein Mali virus-Bazegahot |FM876848.1| & $99 \%$ \\
\hline 47 & Savannah Region & 31-112a/2014 (Tomato) & No found & NS \\
\hline 48 & Savannah Region & 31-112b/2014 (Tomato) & No found & NS \\
\hline 49 & Savannah Region & 31-153/2014 (Tomato) & Tomato leaf curl Nigeria virus-[Nigeria:2006]|FJ685621.1| & $99 \%$ \\
\hline
\end{tabular}

NS $=$ No similarit 


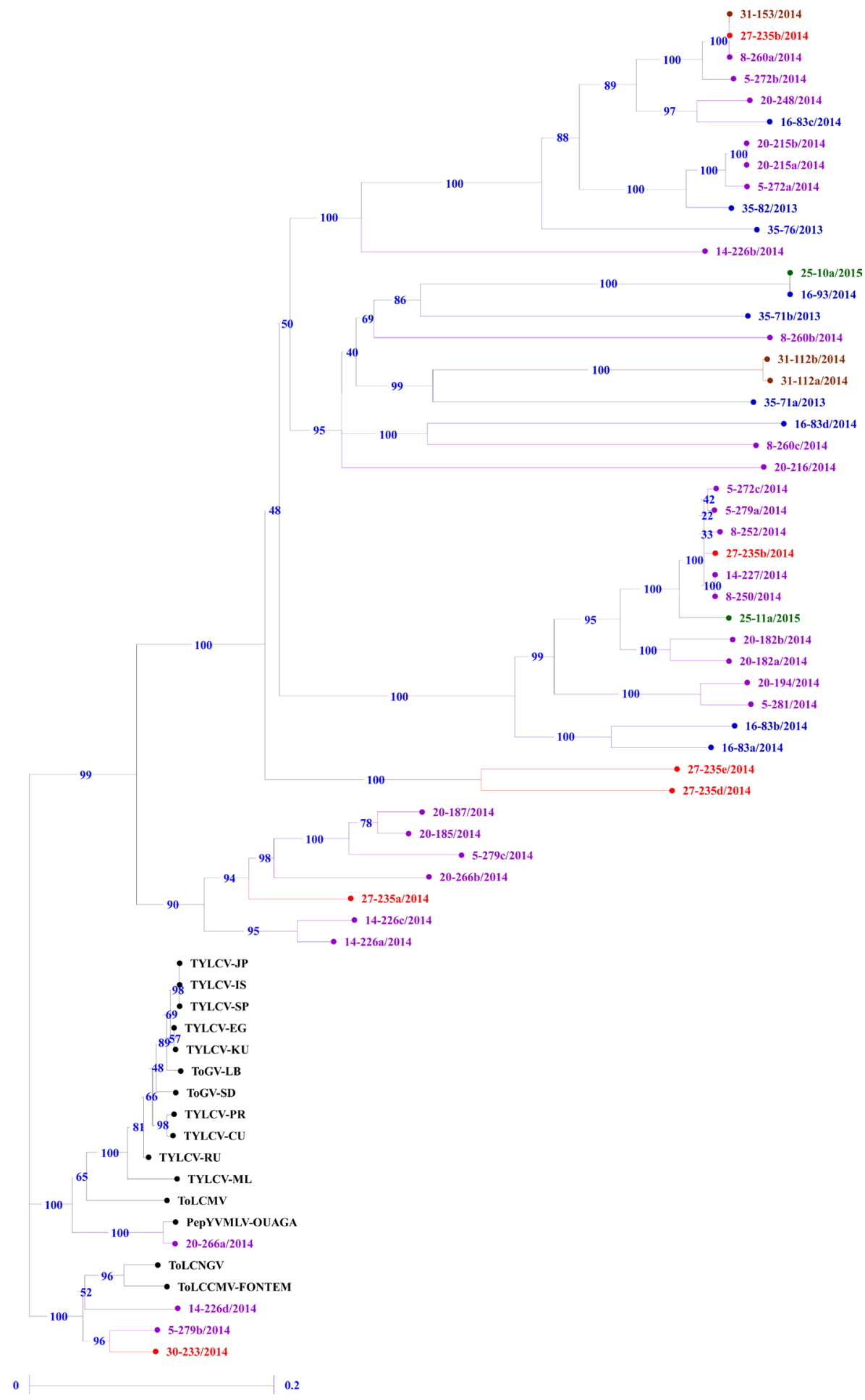

Figure 3. Phylogenetic tree obtained with the DNA sequences of the CP 48 isolates Begomovirus Togo, after Bootstrap analysis with 1000 repetitions performed using the software DARWin5. ToLCMV: Tomato leaf curl Mayotte virus (AJ620914), TOGV-LB: Tomato geminiviruses Lebanon (AF065823), TOGV-SD: Tomato geminiviruses Gezira (AF058030), TYLCV-PR: Tomato yellow leaf curl virus - Puerto Rico (AY134494), TYLCV -RU: Tomato yellow leaf curl virus-Reunion (AJ842307), TYLCV-EG: Tomato yellow leaf curl virus-Egypt (AY594174), TYLCV-IS Tomato yellow leaf curl virus-Israel (AB110218), TYLCV-SP Tomato yellow leaf curl virus-Mild [Spain7297] (AF071228), TYLCV-JP: Tomato yellow leaf curl virus-Mild [Shizuokua] (AB014346), TYLCV-CU Tomato yellow leaf curl virus-Cuba (AJ223505), TYLCV-ML: Tomato yellow leaf curl Mali virus (AY502934), ToLCCMV: Tomato leaf curl Cameroon virus-Fontem (HE659516), PepYVMLV-OUAGA: Pepper yellow vein Mali virus-Ouagadougou (FM876851), TYLCV-KU: Tomato geminiviruses Kuwait (AF065822), ToLCNGV: Tomato leaf curl Nigeria virus (FJ685621). 


\section{Discussion}

In West Africa several viruses infecting tomato crops have been reported, including strains of begomoviruses such as: Tomato leaf curl Cameroon virus (ToLCCMV), Tomato yellow leaf curl Mali virus (TYLCMLV), Tomato leaf curl Nigeria virus (ToLCNGV), Tomato leaf curl Ghana virus (ToLCGHV), Tomato leaf curl Kumasi virus (ToLCKuV) et Tomato leaf curl Togo virus (ToLCTGV) [4] [14] [15] [23] belong the West African tomato infecting begomoviruses (WATIBs) clade. The results in this study revealed that the PCR with virus-specific primers for the Mediterranean TYLCV isolates used by [21], did not succeed in detecting the TYLCD-associated viruses in symptomatic tomato plants and wild plants collected in fields in Togo. However, the degenerate primers of Avcore/ACcore, Deng A/Deng B, Av494/Ac1048, PALIc1960/PARI722 and PAR1c496/ PCRv181 designed respectively by [17] [19] [18] and [20] for geminiviruses succeeded in amplifying the expected band size of geminiviruses of the tested infected samples.

The identification of Tomato leaf curl Cameroon virus-Fontem [24] first in Cameroon and now in Togo suggests that this virus is widely distributed in Central and West Africa. Furthermore, since cultivated tomato is not indigenous to Africa and begomoviruses are not seed transmissible [25], it is more likely that WATIBs originated from an endemic alternate host. The identification of Ageratum leaf curl Cameroon virus first in Ageratum conyzoides and now on tomato in Togo suggests that this begomovirus can infect more than one host. The identification of ALCCMA first in Ageratum conyzoides and now in tomato suggests that ALCCMA may infect more than one host and may be trans-replicated by other begomoviruses. The identification of Tomato leaf curl Nigeria virus [26] on the wild Euphorbia heterophylla in our study suggests that it is a reservoir plant for this virus.

Analysis of the genetic diversity of begomoviruses infecting tomato was carried out by direct sequencing of the PCR products. This strategy, after the PCR parameters were optimized, was extremely efficient for analyzing a large number of sequences in a short period of time. The sequenced region comprises the 5 end of the $\mathrm{CP}$ gene. This is the most variable region of the $\mathrm{CP}$ gene and according to [10], is representative of the variability of the nucleotide sequence of the viral genome. Therefore, phylogenetic analysis based on the region is usually sufficient to establish the taxonomic position of a given isolate of begomoviruses.

From the results obtained from the phylogenetic analysis, sequences from the begomoviruses $\mathrm{CP}$ gene that infect tomato in Togo form seven large groups of begomoviruses. Thus, in groups 6 and 7 there are isolates from Togo mixed with GenBank isolates. But it should also be noted that the elements of the Maritime Region, Central Region, Savannah Region and those of the Kara region can be found together in the same group (G1) and so on. It should be noted that, according to our study, the isolates of begomovirus infecting tomato in Togo are specific to Togo (as shown in the tree of Figure 3 except for two cases where Togo 
isolates are mixed with isolates from GenBank). The proximity of Pepper yellow vein Mali virus-Ouagadougou [27] with a high degree of similarity of $99 \%$ with one of our isolates (20-266a/2014) from the Kara region suggests that this begomovirus has been introduced into this area through the vector insect or trade.

Although, new distinct species of begomovirus were identified in the early 2000s and this, due to increased interest in begomovirus research that has been strengthened, identification and the determination of begomoviruses as emerging viruses and the discovery of new species by viral genome sequencing is the major concern nowadays. [28] have suggested that the South-East of continental Asia could be an important center of diversity for begomoviruses based on the great diversity of strains and species of local monopartite Begomoviruses and associated betasatellite molecules identified in these regions.

\section{Conclusion}

It appears from this study that geographically separated viruses meet and are in mixed infection in Togo. So for the future it would be important to sequence more begomovirus isolates from tomato and wild plants to monitor viral genotypes and to be able to track possible changes in the population structure of these virus. This should be considered when screening programs for virus resistance are established because recombination is permanent with begomoviruses and it is known that when there is recombination, the new recombinants are usually more infectious than their parents.

\section{Acknowledgements}

The Authors wish to express their thanks to the West African Agricultural Productivity Program (WAAPP/TOGO) and Bill and Melinda Gates Foundation (BMGF) for supporting this project.

\section{References}

[1] Brown, J.K., Zerbini, F.M., Navas-Castillo, J., Moriones, E., Ramos-Sobrinho, R., Silva, J.F., Fiallo-Olivé, E., Briddon, R., Hernández-Zepeda, C. and Idris, A. (2015). Revision of Begomovirus Taxonomy Based on Pairwise Sequence Comparisons. Archives of Virology, 160, 1593-1619. https://doi.org/10.1007/s00705-015-2398-y

[2] Tsai, W.S., Shih, S.L., Venkatesan, S.G., Aquino, M.U., Green, S.K., Kenyon, L. and Jan, F.J. (2011) Distribution and Genetic Diversity of Begomoviruses Infecting Tomato and Pepper Plants in the Philippines. Annals of Applied Biology, 158, 275-287. https://doi.org/10.1111/j.1744-7348.2011.00462.x

[3] Van Brunschot, S.L., Bergervoet, J.H., Pagendam, D.E., de Weerdt, M., Geering, A.D., Drenth, A. and Van der Vlugt, R.A. (2013) A Bead-Based Suspension Array for the Multiplexed Detection of Begomoviruses and Their Whitefly Vectors. Journal of Virological Methods, 198, 86-94. https://doi.org/10.1016/j.jviromet.2013.12.014

[4] Zhou, Y.C., Noussourou, M., Kon, T., Rojas, M., Jiang, H., Chen, L.F., Gamby, K., Foster, R. and Gilbertson, R.L. (2008) Evidence of Local Evolution of TomatoInfecting Begomovirus Species in West Africa: Characterization of Tomato Leaf 
Curl Mali Virus and Tomato Yellow Leaf Crumple Virus from Mali. Archives of Virology, 153, 693-706. https://doi.org/10.1007/s00705-008-0042-9

[5] Hanssen, I.M., Lapidot, M. and Thomma, B. (2010) Emerging Viral Diseases of Tomato Crops. Molecular Plant-Microbe Interactions, 23, 539-548. https://doi.org/10.1094/MPMI-23-5-0539

[6] Varsani, A., Navas-Castillo, J., Moriones, E., Hernandez-Zepeda, C., Idris, A., Brown, J.K., Murilo Zerbini, F. and Martin, D.P. (2014) Establishment of Three New Genera in the Family Geminiviridae: Becurtovirus, Eragrovirus and Turncurtovirus. Archives of Virology, 159, 2193-2203. https://doi.org/10.1007/s00705-014-2050-2

[7] Adams, M.J., King, A.M.Q. and Carstens, E.B. (2013) Ratification Vote on Taxonomic Proposals to the International Committee on Taxonomy of Viruses. Archives of Virology, 158, 2023-2030. https://doi.org/10.1007/s00705-013-1688-5

[8] Stanley, J., Bisaro, D.M., Briddon, R.W., Brown, J.K., Fauquet, C.M., Harrison, B.D., Rybicki, E.P. and Stenger, D.C. (2005) Family Geminiviridae. In: Fauquet, C.M., Mayo, M.A., Maniloff, J., Desselberger, U. and Ball, L.A., Eds., Eighth Report of the International Committee on Taxonomy of Viruses, Elsevier Academic Press, 301-326.

[9] Melgarejo, T.A., Kon, T., Rojas, M.R., Paz-Carrasco, L., Zerbini, F.M. and Gilbertson, R.L. (2013) Characterization of a New World Monopartite Begomovirus Causing Leaf Curl Disease of Tomato in Ecuador and Peru Reveals a New Direction in Geminivirus Evolution. Journal of Virology, 87, 5397-5413. https://doi.org/10.1128/JVI.00234-13

[10] Padidam, M., Beachy, R.N. and Fauquet, C.M. (1995) Tomato Leaf Curl Geminivirus from India Has a Bipartite Genome and Coat Protein Is Not Essential for Infectivity. Journal of General Virology, 76, 25-35. https://doi.org/10.1099/0022-1317-76-1-25

[11] Rochester, D.E., Depaulo, J.J., Fauquet, C.M. and Beachy, R.N. (1994) Complete Nucleotide Sequence of the Geminivirus Tomato Yellow Leaf Curl Virus, Thailand Isolate. Journal of General Virology, 75, 477-485. https://doi.org/10.1099/0022-1317-75-3-477

[12] Lefeuvre, P., Martin, D.P., Harkins, G., Lemey, P., Gray, A.J., Meredith, S., Lakay, F., Monjane, A., Lett, J.M., Varsani, A. and Heydarnejad, J. (2010) The Spread of Tomato Yellow Leaf Curl Virus from the Middle East to the World. Plos Pathogens, 6, e1001164. https://doi.org/10.1371/journal.ppat.1001164

[13] Chen, L.F., Rojas, M., Kon, T., Gamby, K., Xoconostle-Cazares, B. and Gilbertson, R.L. (2009) A Severe Symptom Phenotype in Tomato in Mali Is Caused by a Reassortant between a Novel Recombinant Begomovirus (Tomato Yellow Leaf Curl Mali Virus) and a Betasatellite. Molecular Plant Pathology, 10, 415-430. https://doi.org/10.1111/j.1364-3703.2009.00541.x

[14] Leke, W.N., Brown, J.K., Ligthart, M.E., Sattar, N., Njualema, D.K. and Kvarnheden, A. (2011) Ageratum Conyzoides: A Host to a Unique Begomovirus Disease Complex in Cameroon. Virus Research, 163, 229-237. https://doi.org/10.1016/j.virusres.2011.09.039

[15] Osei, M.K., Akromah, R., Shih, S.L., Lee, L.M. and Green, S.K. (2008) First Report and Molecular Characterization of DNA A of Three Distinct Begomoviruses Associated with Tomato Leaf Curl Disease in Ghana. Plant Disease, 92, 1585. https://doi.org/10.1094/PDIS-92-11-1585B

[16] Lohdi, M.A., Ye, G.N., Weeden, N.F. and Reisch, B.I. (1994) A Simple and Efficient Method for DNA Extraction from Grapevine Cultivars and Vitis Species. Plant Mo- 
lecular Biology, 12, 6-13. https://doi.org/10.1007/BF02668658

[17] Brown, J.K., Idris, A., Torres-Jerez, I., Banks, G.K. and Wyatt, S.D. (2001) The Core Region of the Coat Protein Gene Is Highly Useful for Establishing the Provisional Identification and Classification of Begomoviruses. Archives of Virology, 146, 1581-1598. https://doi.org/10.1007/s007050170080

[18] Wyatt, S.D. and Brown, J.K. (1996) Detection of Subgroup III Geminivirus Isolates in Leaf Extracts by Degenerate Primers and Polymerase Chain Reaction. Phytopathology, 86, 1288-1293. https://doi.org/10.1094/Phyto-86-1288

[19] Deng, D., Mcgrath, P.F., Robinson, D.J. and Harrison, B.D. (1994) Detection and Differentiation of Whitefly-Transmitted Geminiviruses in Plants and Vector Insects by the Polymerase Chain Reaction with Degenerate Primers. Annals of Applied Biology, 125, 327-336. https://doi.org/10.1111/j.1744-7348.1994.tb04973.x

[20] Rojas, M.R., Gilbertson, R.L., Russell, D.R. and Maxwell, D.P. (1993) Use of Degenerate Primers in the Polymerase Chain Reaction to Detect Whitefly-Transmitted Geminiviruses. Plant Disease, 77, 340-347. https://doi.org/10.1094/PD-77-0340

[21] Anfoka, G.H., Abhary, M. and Nakhla, M.K. (2005) Molecular Identification of Species of the Tomato Yellow Leaf Curl Virus Complex in Jordan. Journal of Plant Pathology, 87, 65-70. https://doi.org/10.4454/jpp.v87i1.898

[22] Larkin, M.A., Blackshields, G., Brown, N.P., Chenna, R., Mcgettigan, P.A., Mcwilliam, H., Valentin, F., Wallace, I.M., Wilm, A., Lopez, R., Thompson, J.D., Gibson, T.J. and Higgins, D.G. (2007) Clustal W and Clustal X Version 2.0. Bioinformatics Applications, 23, 2947-2948. https://doi.org/10.1093/bioinformatics/btm404

[23] Kon, T., Rojas, M.R., Abdourhamane, I.K. and Gilbertson, R.L. (2009) Roles and Interactions of Begomoviruses and Satellite DNAs Associated with Okra Leaf Curl Disease in Mali, West Africa. Journal of General Virology, 90, 1001-1013. https://doi.org/10.1099/vir.0.008102-0

[24] Leke, W.N. and Kvarnheden, A (2014) Mixed Infection by Two West African Tomato-Infecting Begomoviruses and Ageratum Leaf Curl Cameroon Betasatellite in Tomato in Cameroon. Archives of Virology, 159, 3145-3148. https://doi.org/10.1007/s00705-014-2159-3

[25] Inoue-Nagata, A.K., Lima, M.F. and Gilbertson, R.L. (2016) A Review of Geminivirus (Begomovirus) Diseases in Vegetables and Other Crops in Brazil: Current Status and Approaches for Management. Horticultura Brasileira, 34, 8-18. https://doi.org/10.1590/S0102-053620160000100002

[26] Kon, T. and Gilbertson, R.L. (2012) Two Genetically Related Begomoviruses Causing Tomato Leaf Curl Disease in Togo and Nigeria differ in Virulence and Host Range But Do Not Require a Betasatellite for Induction of Disease Symptoms. Archives of Virology, 157, 107-120. https://doi.org/10.1007/s00705-011-1139-0

[27] Tiendrébéogo, F., Lefeuvre, P., Hoareau, M., Traoré, V.S., Barro, N., Péréfarres, F., Reynaud, B., Traoré, A.S., Konaté, G., Lett, J.M. and Traoré, O. (2011) Molecular and Biological Characterization of Pepper Yellow Vein Mali Virus (PepYVMV) Isolates Associated with Pepper Yellow Vein Disease in Burkina Faso. Archives of Virology, 156, 483-487. https://doi.org/10.1007/s00705-010-0854-2

[28] Ha, C., Coombs, S., Revill, P., Harding, R., Vu, M. and Dale, J. (2008) Molecular Characterization of Begomoviruses and DNA satellites from Vietnam: Additional Evidence That the New World Geminiviruses Were Present in the Old World Prior to Continental Separation. Journal of General Virology, 89, 312-326. https://doi.org/10.1099/vir.0.83236-0 